Fakultas Hukum Universitas Lancang Kuning, Jalan Yos Sudarso KM 8 Rumbai Pekanbaru, Riau, Kode Pos 28266. Telp: (+62761)-51877

E-mail: jurnal.respublica@ac.id

Website: https://journal.unilak.ac.id/index.php/Respublica

\title{
Tanggungjawab Pihak Pengembang Perumahan Berdasarkan Perjanjian Jual Beli dengan Konsumen di Kota Pekanbaru
}

\author{
Frans Mitrano $^{\mathrm{a}}$ \\ ${ }^{a}$ Polresta Pekanbaru, Riau, Indonesia, Email: fransmitrano@gmail.com
}

\section{Article Info}

Article History:

Received : 28-09-2020

Revised : 10-10-2020

Accepted : 11-11-2020

Published : 28-11-2020

\section{Keywords:}

Developer

Housing

Agreement

\section{Informasi Artikel}

\section{Histori Artikel:}

Diterima : 28-09-2020

Direvisi : $10-10-2020$

Disetujui : 11-11-2020

Diterbitkan : 28-11-2020

\section{Kata Kunci:}

Pengembang

Perumahan

Perjanjian

\begin{abstract}
Housing is a group of houses that function as a residential area equipped with environmental infrastructure, namely the basic physical features of the environment, for example the provision of drinking water, garbage disposal, availability of electricity, telephone, roads, which enable the residential environment to function properly. Home is a place to let go of fatigue, a place to hang out, and foster a sense of kinship among family members, a place for family shelter and to store valuables. A house is a physical structure consisting of a room, yard and surrounding area which is used as a place to live and a means of family formation. According to WHO (World Health Organization), a house is a physical structure or a building for shelter, where the environment is useful for physical and spiritual health and social conditions, both for family and individual health. The main issue is what is the responsibility of the housing developer based on the sale and purchase agreement with consumers in the city of Pekanbaru and what are the legal consequences of the responsibility of the housing developer based on the sale and purchase agreement with consumers in the city of Pekanbaru. As for this research is a sociological legal research, so this research is descriptive analysis Abstract
\end{abstract}

\begin{abstract}
Abstrak
Perumahan adalah kelompok rumah yang berfungsi sebagai lingkungan tempat tinggal hunian yang dilengkapi dengan prasarana lingkungan yaitu kelengkapan dasar fisik lingkungan, misalnya penyediaan air minum, pembuangan sampah, tersedianya listrik, telepon, jalanan, yang memungkinkan lingkungan pemukiman berfungsi sebagaimana mestinya. Rumah adalah tempat untuk melepaskan lelah, tempat bergaul, dan membina rasa kekeluargaan diantara anggota keluarga, tempat berlindung keluarga dan menyimpan barang berharga. Rumah adalah struktur fisik yang terdiri dari ruangan, halaman dan area sekitarnya yang dipakai sebagai tempat tinggal dan sarana pembinaan keluarga. Menurut WHO (World Health Organization), rumah adalah struktur fisik atau bangunan tempat berlindung, di mana lingkungan berguna untuk kesehatan jasmani dan rohani serta keadaan sosialnya, baik untuk kesehatan keluarga dan individu. Adapun pokok masalah apakah Tanggung Jawab Pihak Pengembang Perumahan Berdasarkan Perjanjian Jual Beli Dengan Konsumen Di Kota Pekanbaru dan apakah Akibat Hukum Dari Tanggung Jawab Pihak Pengembang Perumahan Berdasarkan Perjanjian Jual Beli Dengan Konsumen Di Kota Pekanbaru. adapun penelitian ini merupakan penelitian hukum sosiologis sehingga penelitian ini bersifat deskriftif analisis Abstrak
\end{abstract}




\section{PENDAHULUAN}

Pasal 134 Undang-undang Nomor 1 Tahun 2011 Tentang Perumahan dan Kawasan Permukiman mengatakan bahwa setiap orang dilarang menyelenggarakan pembangunan perumahan, yang tidak membangun perumahan sesuai dengan kriteria, spesifikasi, persyaratan, prasana, sarana, dan utilitas umum yang diperjanjikan". Maka dalam hal ini, penjual dianggap melakukan wanprestasi dengan tidak memenuhi kewajibannya dalam perjanjian jual beli kesepekatan bersama.

Berdasarkan pasal ini pengembang wajib melaksanakan aturan yang sesuai dengan kriteria, spesifikasi, persyaratan, prasana, sarana, dan utilitas umum yang diperjanjikan. Tanggung jawab pengembang mestinya melakukan pekerjaan yang sesuai dengan apa yang diperjanjikan, dalam hal ini memenuhi sarana (tempat ibadah, saluran / parit, taman), prasarana (jalan dan listrik), utilitas umum (keamanan), serta juga kriteria perumahan sesuai dengan spesifikasi dasarnya.

Perjanjian adalah suatu perbuatan hukum dimana seorang atau lebih mengkatkan dirinya terhadap seorang lain atau lebih. ${ }^{1}$ Menurut Abdulkadir Muhammad, perjanjian adalah: ${ }^{2}$ Suatu persetujuan dengan dua orang atau lebih saling mengikatkan diri untuk melaksanakan suatu hal dalam lapangan harta kekayaan. Dalam definisi tersebut, secara jelas terdapat konsensus antara para pihak, yaitu persetujuan antara pihak satu dengan pihak lainnya. Selain itu juga, perjanjian yang dilaksanakan terletak pada lapangan harta kekayaan.

Dalam Membuat sebuah perjanjian tidak terlepas dari syarat sahnya sebuah perjanjian. Syarat-syarat sahnya perjanjian diatur dalam pasal 1320 KUHPerdata. Hal ini sangat perlu dipahami agar tercipta sebuah perjanjian yang sah. Di dalam pasal 1320 KUHPerdata disebut empat syarat agar sebuah perjanjian itu dapat dikatakan sah, yaitu: ${ }^{3}$

1. Sepakat bagi mereka yang mengikatnya, dimana para pihak yang mengadakan perjanjian tersebut harus sepakat dan setuju dengan apa yang akan diperjanjian tanpa adanya suatu paksaan atau kekhilafan;

2. Kecakapan untuk membuat suaut perjanjian, Dimana para pihak harus memiliki kecakapan menurut hukum diantara sudah dewasa dan dalam keadaan sehat;

\footnotetext{
${ }^{1}$ Sri Soedewi Masjchoen Sofwan, Hukum Perjanjian, (Yogyakarta: Universitas Gadjah Mada, 1982), 8.

${ }^{2}$ Abdul Kadir Muhammad, Hukum Perikatan, (Bandung: Citra Aditya Bakti, 1990), 4.

${ }^{3}$ Ni Luh Putu Eka Wijayanti, Keabsahan Sebuah Perjanjian Berdasarkan Dari Kitab Undang-Undang Hukum Perdata, Bagian Hukum Bisnis Fakultas Hukum Universitas Udayana, 53.
} 
3. Suatu hal tertentu, Dimana dalam perjanjian tersebut telah ditentukan objek dari perjanjian atau hal yang diperjanjikan; dan

4. Suatu sebab yang halal, Dimana dalam perjanjian ini harus didasari dengan hal-hal yang tidak bertentangan dengan undang-undang yang berlaku. Pasal 1337 menerangkan bahwa yang dimaksud sebab yang halal yaitu tidak bertentangan dengan kepatutan, ketertiban umum, dan peraturan perundang-undangan.

Pengembang perumahan dalam menjalankan kegiatannya biasanya masuk kedalam asosiasi yang yang mempunyai Visi-Misi sejalan dengan pengembang perumahan tersebut. Beberapa asosiai perumahan yang ada di Indonesia di antaranya, APERSI (Asosiasi Pengembang Perumahan dan Kawasan Permukiman Seluruh Indonesia), REI (Persatuan Perusahaan Realestat Indonesia)

Namun pada kenyataanya pengembang tidak menjalankan pasal 134 Undang-undang Nomor 1 Tahun 2011 Tentang Perumahan dan Kawasan Permukiman, hal ini terlihat dari ketika pembeli akan atau selama menempati rumah yang siap dihuni ternyata rumah yang dijanjikan tidak bisa digunakan selayaknya dikarenakan bangunan rumah mengalami kecacatan misalnya pada tembok, lantai dan pada konstruksi utama atau tidak sesuai dengan spesifikasi yang telah ditawarkan atau diperjanjikan, serta sarana, prasarana, dan utilitas umum yang tidak memadai bahkan jauh dari kata layak.

Seperti beberapa pengembang yang di Perumahan Grand Maharatu, Perumahan The Kartama, Perumahan Bafanda, Perumahan Griya Padat Karya, dan Perumahan Griya Setia Nusa. Beberapa tempat perumahan di Kota Pekanbaru banyak dijumpai bahwa terdapat perumahan yang tidak dilengkapi dengan sarana, prasarana, bahkan utilitas umum serta kondisi yang diperjanjikan tidak sesuai spesifikasi dan kriteria yang diberikan. Dalam membangun perumahan diwajibkan kepada pengembang untuk melengkapi fasilitas perumahan sesuai dengan amanat peraturan perundang-undangan. Berdasarkan observasi penulis, di Kota Pekanbaru terdapat lima perumahan yang tidak menjalankan aturan tersebut, antara lain :

1. Perumahan Grand Maharatu yang terletak di jalan Suhada Kelurahan Maharatu ini tidak melakukan semenisasi/aspal dalam lokasi perumahan

2. Perumahan The Kartama yang terletak di jalan Kartama, bahwa permasalahannya tidak adanya sarana seperti tempat ibadah (Musholla/Masjid) 
3. Perumahan Bafanda yang terletak di jalan Indrapuri, bahwa terdapat permasalahan tidak dilengkapi dengan sarana maupun utilitas umum, karena di perumahan tersebut tempat ibadah (Musholla/Masjid) ini tidak ada, serta keamanan yang belum terealisasikan

4. Perumahan Griya Padat Karya, yang terletak di jalan Padat Karya Rumbai ini belum merealisasikan jalan, sarana, dan tempat ibadah (Musholla/Masjid)

5. Perumahan Griya Setia Nusa, yang terletak di Kubang ini tidak melakukan kewajibannya untuk membangun dan merealisasikan untuk jalan yang belum semenisasi/aspal dan beberapa pembangunan sarana belum dilakukan pihak pengembang.

Permasalahan yang akan di bahas dalam penelitian ini adalah bagaimanakah tanggung jawab pihak pengembang perumahan berdasarkan perjanjian jual beli dengan konsumen di Kota Pekanbaru dan bagaimanakah akibat hukum dari tanggung jawab pihak pengembang perumahan berdasarkan perjanjian jual beli dengan konsumen di Kota Pekanbaru. Jenis penelitian ini adalah sosiologis, sehingga sumber data yang digunakan adalah data primer dari wawancara, data sekunder dari perpustakaan dan data tersier dari kamus, media, dan ensiklopedia. Teknik pengumpulan data dilakukan dengan observasi, wawancara, dan kajian kepustakaan

Tujuan penelitian yang dilakukan penulis Untuk mengetahui lebih jelas untuk menganalisis tanggung jawab pihak pengembang perumahan berdasarkan perjanjian jual beli dengan konsumen di Kota Pekanbaru dan untuk menganalisis akibat hukum dari tanggung jawab pihak pengembang perumahan berdasarkan perjanjian jual beli dengan konsumen di Kota Pekanbaru.

Tanggung Jawab Pihak Pengembang Perumahan Berdasarkan Perjanjian Jual Beli Dengan Konsumen Di Kota Pekanbaru

Sejalan dengan pertumbuhan penduduk yang makin pesat, tuntutan akan tersedianya berbagai fasilitas yang mendukung kehidupan masyarakat juga mengalami peningkatan. Setiap individu selalu berkeinginan agar rumah yang dihuninya memenuhi standar kesehatan, 
standar konstruksi, tersedianya fasilitas umum, fasilitas sosial dan prasarana lingkungan yang memadai. $^{4}$

Pada dasarnya, ketersediaan sarana perumahan tersebut merupakan kewajiban penyelenggara pembangunan perumahan dan pemukiman. ${ }^{5}$ Hal ini dapat dilihat dalam Undang-Undang Nomor 1 tahun 2011 tentang Perumahan dan Kawasan Pemukiman. Dalam pasal 19 Undang-Undang Nomor 1 tahun 2011 dinyatakan bahwa penyelenggaraan rumah dan perumahan dilakukan untuk memenuhi kebutuhan rumah sebagai salah satu kebutuhan dasar manusia bagi peningkatan dan pemerataan kesejahteraan rakyat. Penyelenggaraan rumah dan perumahan dilaksanakan oleh Pemerintah, Pemerintah Daerah, dan/atau setiap orang yang menjamin hak setiap warga negara untuk menempati, menikmati, dan/atau memiliki rumah yang layak dalam lingkungan yang sehat, aman, serasi, dan teratur. ${ }^{6}$

Perumahan adalah kelompok rumah yang berfungsi sebagai lingkungan tempat tinggal hunian yang dilengkapi dengan prasarana lingkungan yaitu kelengkapan dasar fisik lingkungan, misalnya penyediaan air minum, pembuangan sampah, tersedianya listrik, telepon, jalanan, yang memungkinkan lingkungan pemukiman berfungsi sebagaimana mestinya. Rumah adalah tempat untuk melepaskan lelah, tempat bergaul, dan membina rasa kekeluargaan diantara anggota keluarga, tempat berlindung keluarga dan menyimpan barang berharga. Rumah adalah struktur fisik yang terdiri dari ruangan, halaman dan area sekitarnya yang dipakai sebagai tempat tinggal dan sarana pembinaan keluarga. Menurut WHO (World Health Organization), rumah adalah struktur fisik atau bangunan tempat berlindung, di mana lingkungan berguna untuk kesehatan jasmani dan rohani serta keadaan sosialnya, baik untuk kesehatan keluarga dan individu.

Berdasarkan Undang-Undang No. 1 Tahun 2011 tentang Perumahan dan Pemukiman, terdapat beberapa pengertian dasar, yaitu:

1. Rumah adalah bangunan yang berfungsi sebagai tempat tinggal atau hunian dan sarana pembinaan keluarga.

2. Perumahan adalah kelompok rumah yang berfungsi sebagai lingkungan tempat tinggal atau lingkungan hunian yang dilengkapi dengan prasarana dan sarana lingkungan.

\footnotetext{
${ }^{4}$ Mursalim, Perencanaan Dan Pembuatan Fasilitas Perumahan, (Jakarta: Citra Adithya Bakti, 2002$), 84$.

${ }^{5}$ Ajiraksa, Perencanaan Dan Pengembang Perumahan, (Jakarta: Citra Adithya Bakti, 2002), 182.

6 Soedjajadi Keman, Kesehatan Perumahan Dan Lingkungan Pemukiman, Surabaya: Jurnal Kesehatan Lingkungan, Fakultas Kesehatan Masyarakat Univ. Airlangga, Vol. 2, No. 1, 2005, hlm 30
} 
3. Permukiman adalah satuan kawasan perumahan lengkap dengan prasarana lingkungan, prasarana umum, dan fasilitas sosial yang mengandung keterpaduan kepentingan dan keelarasan pemanfaatan sebagai lingkungan kehidupan.

4. Prasarana adalah kelengkapan dasar fisik lingkungan hunian yang memenuhi standar tertentu untuk kebutuhan bertempat tinggal yang layak, sehat, aman, dan nyaman.

5. Sarana adalah fasilitas dalam lingkungan hunian yang berfungsi untuk mendukung penyelenggaraan dan pengembangan kehidupan sosial, budaya, dan ekonomi.

6. Utilitas umum adalah kelengkapan penunjang untuk pelayanan lingkungan hunian.

Menurut Suparno Sastra M. dan Endi Marlina, pengertian mengenai perumahan adalah sekelompok rumah yang berfungsi sebagai lingkungan tempat tinggal atau lingkungan hunian yang dilengkapi dengan prasarana dan dan sarana lingkungan. ${ }^{7}$ Sedangkan permukiman menurut Suparno Sastra M. dan Endi Marlina, adalah suatu tempat bermukim manusia untuk menunjukkan suatu tujuan tertentu. Apabila dikaji dari segi makna, permukiman berasal dari terjemahan kata settlements yang mengandung pengertian suatu proses bermukim. Pemukiman memiliki arti yang berbeda yaitu: ${ }^{8}$

a. Isi; yaitu menunjuk pada manusia sebagai penghuni maupun masyarakat di lingkungan sekitarnya

b. Wadah; yaitu menunjuk pada fisik hunian yang terdiri dari alam dan elemen-elemen buatan manusia.

Menurut pasal 5 tahun 1974 disebutkan pengertian Perusahaan Pembangunan Perumahan yang dapat pula masuk dalam pengertian Pengembang Perumahan, yaitu: "Perusahaan Pembangunan Perumahan adalah suatu perusahaan yang berusaha dalam bidang pembangunan perumahan dari berbagai jenis dalam jumlah yang besar di atas suatu areal tanah yang akan merupakan suatu kesatuan lingkungan pemukiman yang dilengkapi dengan prasarana-prasarana lingkungan dan fasilitas-fasilitas social yang diperlukan oleh masyarakat penghuninya".

Dalam Undang-Undang No.1 tahun 2011 tentang Perumahan dan Kawasan Permukiman (UU No 1 tahun 2011) pengembang perumahan masuk dalam kategori penyelenggara atau pengembang pembangunan perumahan dan pemukiman yang penyelenggaraan rumah dan perumahan dilalaksanakan oleh Pemerintah, Pemerintah Daerah

\footnotetext{
${ }^{7}$ Didik Rianto, Perencanaan Dan Pembangunan Perumahan, (Surabaya: PT. Tabah Jaya, 2006), 29.

${ }^{8}$ Ibid., hlm 37
} 
dan/atau setiap orang untuk menjamin hak setiap warga Negara untuk menempati, menikmati, dan/atau memiliki rumah yang layak dalam lingkungan yang sehat, aman, serasi, dan teratur.

Dimulai dengan tahap perencanaan, pada tahap ini meliputi izin lokasi, izin perencanaan, IMB, serta bagaimana status tanah tempat fasilitas sosial direncanakan. Aspek pengawasan pada tahap perencanaan saat pengembang mengajukan izin pembangunan kompleks perumahan merupakan tahap pengendalian awal. Pengendalian ini diharapkan nantimya dalam tahap pembangunan dapat sesuai dengan apa yang diajukan sesuai dengan rencana/perizinan yang didapat.

Kemudian dilanjutkan pada tahap pembangunan yang mana pada tahap ini tanah dimatangkan dan diatasnya dibangun rumah dan fasilitas-fasilitasnya sebagaimana yang dinyatakan dalam rencana proyek yang telah disetujui. Dalam tahap ini peran Pemerintah Daerah dalam mengawasi pembangunan perumahan dan fasilitas sosial agar sesuai standar dan peraturan yang berlaku sangatlah besar. Pelaksanaan pengawasan dan pengendalian ini dilaksanakan oleh dinas PU dan instansi terkait secara berkelanjutan agar pelanggaran terhadap pembangunan fasilitas sosial dan fasilitas umum dapat dihindari.

Dalam Tanggung Jawab Pihak Pengembang Perumahan Berdasarkan Undang Undang Nomor 1 Tahun 2011 Tentang Perumahan Dan Kawasan Permukiman Di Kota Pekanbaru. Peneliti dalam hal ini melakukan penelitian di Dinas Pekerjaan Umum Kota Pekanbaru, Dinas Perumahan Kawasan Permukiman Kota Pekanbaru, Pengembang Perumahan Kota Pekanbaru, dan Pembeli / Konsumen, yang mencakup dua pejabat yaitu Kepala Dinas Pekerjaan Umum Kota Pekanbaru. Dan untuk mendapatkan data yang lebih valid, peneliti melakukan penelitian dengan Kepala Dinas Perumahan Kawasan Permukiman Kota Pekanbaru. Data yang peneliti temukan di Dinas Pekerjaan Umum Kota Pekanbaru yaitu melalui wawancara dengan Kepala Dinas bapak Indra Pomi Nasution, M.Si. Data wawancara di dapat beberapa jawaban mengenai persoalan Tanggung Jawab Pihak Pengembang Perumahan Berdasarkan Undang Undang Nomor 1 Tahun 2011 Tentang Perumahan Dan Kawasan Permukiman Di Kota Pekanbaru.

Menurut bapak Indra Pomi Nasution, M.Si selaku Kepala Dinas Pekerjaan Umum Kota Pekanbaru yang penulis wawancarai mengatakan bahwa perumahan-perumahan ini memang ada kaitannya dengan PUPR, tapi secara umum pembinaan dibawah dinas perumahan dan permukiman. Kaitannya dengan PUPR ini dalam memberikan izin mendirikan bangunan, dimana dalam pemberian izin tersebut sudah ada prosedur dan mekanisme yang 
dilalui, terutama harus ke pelayanan publik dulu. Dan nantinya mal pelayanan publik yang meneruskan ke PUPR. Dalam hal ini juga melibatkan para ahli sebelum memberikan izin. ${ }^{9}$

Lebih lanjut, ia mengatakan bahwa berkaitan dengan fasilitas umum seperti musholla, lapangan, MCK, dan juga bangunan sosial lainnya itu, itu memang dipersyaratkan dan itu menjadi bagian yang diperiksa oleh tim, namun ketika pengembang mengurus izin, pengembang menyetujui itu. Dimana tempat seperti jalan, parit, musholla, lapangan sudah ditentukan, kenyataanya sebagian besar fasos dan fasus tidak dilakukan pengembang. ${ }^{10}$

Menurut bapak Ardani ST.MT selaku Kepala Dinas Perumahan Kawasan Permukiman Kota Pekanbaru mengatakan bahwa tanggungjawab pengembang dalam hal ini pengembang mestinya harus taat pada mekanisme yang ada, dimana di dalam mekanisme tersebut sudah ada petunjuk dan perintah supaya menyediakan prasarana dan sarana yang memadai. $^{11}$

Menurut bapak Indra Pomi Nasution, M.Si selaku Kepala Dinas Pekerjaan Umum Kota Pekanbaru yang penulis wawancarai mengatakan bahwa berkaitan fasos dan fasum yang ada di dalam rencana pembangunan, namun pada kenyataanya tidak ada, inilah instrument yang sebenarnya agak lemah pemerintah disini, seharusnya PTSP sebagai yang memberikan izin dan yang mempunyai tim, maka harus dilakukan pengecekan dan pengawasan, sekarang pengawasan itulah yang tidak ada, pemerintah dalam hal ini harus membentuk pengawasan supaya tau apakah izin yang diberikan sudah dilaksanakan atau belum pada tahap pembangunan. $^{12}$

Seperti beberapa pengembang yang di Perumahan Grand Maharatu, Perumahan The Kartama, Perumahan Bafanda, Perumahan Griya Padat Karya, dan Perumahan Griya Setia Nusa. Beberapa tempat perumahan di Kota Pekanbaru banyak dijumpai bahwa terdapat perumahan yang tidak dilengkapi dengan sarana, prasarana, bahkan utilitas umum serta kondisi yang diperjanjikan tidak sesuai spesifikasi dan kriteria yang diberikan. Dalam membangun perumahan diwajibkan kepada pengembang untuk melengkapi fasilitas perumahan sesuai dengan amanat peraturan perundang-undangan.

\footnotetext{
${ }^{9}$ Wawancara dengan bapak Indra Pomi Nasution, M.Si selaku Kepala Dinas Pekerjaan Umum Kota Pekanbaru, pada tanggal 13 Maret 2020

10 Ibid

11 Wawancara dengan bapak Ardani ST.MT selaku Kepala Dinas Perumahan Kawasan Permukiman Kota Pekanbaru, pada tanggal 4 Maret 2020

${ }^{12}$ Wawancara dengan bapak Indra Pomi Nasution, M.Si selaku Kepala Dinas Pekerjaan Umum Kota Pekanbaru, pada tanggal 13 Maret 2020
} 
Kasus yang terjadi Perumahan Grand Maharatu yang terletak di jalan Suhada Kelurahan Maharatu ini tidak melakukan semenisasi/aspal dalam lokasi perumahan, bahkan ada beberapa konsumen yang ingin meminta ganti rugi atau perbaikan terhadap fasilitas. Berdasarkan observasi penulis dilapangan, bahwa masih banyak ditemukan perumahan yang tidak melaksanakan sesuai dengan kriteria dan tidak menyediakan fasos dan fasum (sarana, prasarana, utilitas umum).

Berdasarkan hasil wawancara dengan bapak Slamet selaku Pengembang Perumahan Grand Maharatu mengatakan bahwa dalam pembangunan sudah dijalankan, namun apabila ada kerusakan itu ketahanan dari pada tanah dan bangunan karena faktor cuaca ataupun bentuk tanah ${ }^{13}$

Kasus yang terjadi Perumahan Bafanda yang terletak di jalan Indrapuri, bahwa terdapat permasalahan tidak dilengkapi dengan sarana maupun utilitas umum, karena di perumahan tersebut tempat ibadah (Musholla/Masjid) ini tidak ada, serta keamanan yang belum terealisasikan, ini para pengembang tidak melakukan apa yang menjadi kewajiban pembangunan, dimana para konsumen ingin meminta ganti rugi

Berdasarkan hasil wawancara dengan bapak M. Nur selaku Pengembang Perumahan Bafanda mengatakan bahwa tanggungjawab seperti perumahan sudah dibangun sesuai dengan spesifikasi, dan untuk bangunan seperti sarana, prasarana, dan utilitas umum sudah dijalankan, namun pada tahap pembangunan masih kurang di pendanaan. ${ }^{14}$

Kasus yang terjadi pada Perumahan Griya Padat Karya, yang terletak di jalan Padat Karya Rumbai ini belum merealisasikan jalan, sarana, dan tempat ibadah (Musholla/Masjid). Dimana juga para pengembang belum merealisasikan sarana, prasarana, dan utilitas umumnya. Para sebagian konsumen di perumahan tersebut ingin meminta gantu rugi kepada pengembang.

Kewajiban dan tanggung jawab pengembang perumahan terdapat dalam pasal $19 \mathrm{UU}$ No. 1 tahun 2011 dinyatakan bahwa penyelenggaraan rumah dan perumahan dilakukan untuk memenuhi kebutuhan rumah sebagai salah satu kebutuhan dasar manusia bagi peningkatan dan pemerataan kesejahteraan rakyat.

\footnotetext{
${ }^{13}$ Wawancara dengan bapak Slamet selaku Pengembang Perumahan Grand Maharatu, pada tanggal 17 Februari 2020

${ }^{14}$ Wawancara dengan bapak M. Nur selaku Pengembang Perumahan Bafanda, pada tanggal 24 Februari 2020
} 
Pada dasarnya penyelenggaran perumahan tersebut tidak terlepas dari penyelenggaraan sarana. Berdasarkan Pasal 20 ayat (1) UU No. 1 tahun 2011, penyelenggaran perumahan meliputi:

1. perencanaan perumahan;

2. pembangunan perumahan;

3. pengendalian perumahan.

Perumahan yang dimaksud mencakup rumah atau perumahan beserta prasarana, sarana, dan utilitas umum (Pasal 20 ayat (2) UU No. 1 tahun 2011). Hal ini juga ditegaskan kembali dalam pasal 32 ayat (1) UU No. 1 tahun 2011, yang mengatakan bahwa pembangunan perumahan meliputi:

1. pembangunan rumah dan prasarana, sarana, dan utilitas umum; dan/atau

2. peningkatan kualitas perumahan.

Berdasarkan standar pelayanan minimal dalam Peraturan Menteri Negara perumahan rakyat Republik Indonesia Nomor : 22/PERMEN/M/2008 Tentang Standar Pelayanan Minimal Bidang Perumahan Rakyat Daerah Provinsi Dan Daerah Kabupaten Kota untuk cakupan lingkungan yang sehat dan aman yang didukung prasarana, sarana dan utilitas umum. $^{15}$

Pemakaman merupakan sarana perumahan dan pemukiman yg harus disediakan, maka pihak yang membangun perumahan tersebut wajib menyediakan sarana pemakaman. Kewajiban adanya sarana ini juga diperlihatkan dalam pasal 42 ayat (1) jo. Pasal 42 ayat (2) UU No. 1 tahun 2011 yang mengatakan bahwa rumah tunggal, rumah deret, dan/atau rumah susun yang masih dalam tahap proses pembangunan dapat dipasarkan melalui sistem perjanjian pendahuluan jual beli. Perjanjian jual beli dilakukan setelah memenuhi persyaratan kepastian atas:

1. status kepemilikan tanah;

2. hal yang diperjanjikan;

3. kepemilikan izin mendirikan bangunan induk;

4. ketersediaan prasarana,sarana, dan utilitas umum; dan

5. keterbangunan perumahan paling sedikit $20 \%$ (dua puluh persen).

\footnotetext{
${ }^{15}$ Peraturan Menteri Negara perumahan rakyat Republik Indonesia Nomor : 22/PERMEN/M/2008 Tentang Standar Pelayanan Minimal Bidang Perumahan Rakyat Daerah Provinsi Dan Daerah Kabupaten Kota
} 
Berdasarkan uraian diatas, dapat dikatakan bahwa pemakaman sebagai salah satu sarana perumahan dan pemukiman, merupakan suatu kewajiban yang seharusnya diperjanjikan juga oleh pembangun. Dalam pasal 134 UU No 1 tahun 2011, dikatakan bahwa "setiap orang dilarang menyelenggarakan pembangunan perumahan, yang tidak membangun perumahan sesuai dengan kriteria, spesifikasi, persyaratan, prasarana, sarana, dan utilitas umum yang diperjanjikan.

Dalam transaksi jual-beli rumah melibatkan sekurang-kurangnya ada 3 (tiga) pihak yang berhubungan antara satu dengan lainnya, yaitu konsumen, pengembang, dan bank (pemberi kredit). Adapun transaksi jual-beli rumah dapat dilakukan melalui tiga tahapan, yaitu :

\section{Pra Kontraktual}

Tahap ini merupakan persiapan bagi konsumen sebelum memastikan membeli rumah yang diminati. Ada beberapa hal penting yang perlu diperhatikan konsumen sebelum mengambil keputusan untuk membeli rumah kepada pengembang yang dipilih, yaitu :

a. Lokasi rumah, dalam hal ini seorang konsumen harus melakukan identifikasi terhadap lokasi rumah yang akan dibeli. Apakah lokasinya telah sesuai dengan keinginan dan kebutuha konsumen. Bila perlu, harus ada peninjuan terlebih dahulu terhadap lokasi perumahan yang akan dibeli.

b. Identitas pengembang, hal penting lain adalah mengenal identitas pengembang. Identitas dapat memberikan informasi tentang prestasi pengembang. Sejauhmana kiprahnya sebagai pengembang, apakah sering bermasalah, atau mungkin tipe pengembang yang mengekploitasi hak-hak konsumen. Kecukupan informasi pengembang akan memantapkan pilihan didalam membeli rumah.

c. Perizinan, sebelum mengambil keputusan membeli, masalah perizinan harus terlebih dahulu dikonfirmasikan. Apakah pihak pengembang telah memenuhi berbagai prosedur perizinan pembangunan rumah dan berbagai bentuk perizinan terkait?. Apabila informasi ini telah jelas, maka memdahkan konsumen untuk menentukan pilhan layak atau tidak untuk membeli.

d. Spesifikasi teknis bangunan, langkah ini ditempuh untuk menghindari akibat samping yang ditimbulkan dari pembangunan rumah yang tidak sesuai dengan prosedur teknis. Hal ini juga akan membantu konsumen di dalam menentukan pilihan spesifikasi teknis yang sesuai dengan keinginannya. Karena tidak dapat 
dipungkiri seringkali spesifikasi teknis yang ada pada brosur menyimpang dari standar spesifikasi yang senyatanya.

e. Fasilitas yang tersedia dalam rumah, untuk menghindari hal yang tidak diinginkan perlu kiranya ditanyakan berbagai fasilitas yang tersedia di dalam rumah. Fasilitas yang tersedia dapat memberikan gambaran kepada konsumen berapa besar biaya yang harus dikeluarkan untuk membeli rumah jika dibandingkan dengan fasilitas yang tersedia. Apakah fasilitas yang tersedia telah layak dengan harga jual yang ditawarkan oleh pengembang.

f. Prasarana dan sarana lingkungan, kenyamanan sebuah rumah adalah tersedianya sarana dan prasarana yang memadai. Karena ini juga merupakan sebuah kebutuhan, maka harus benar-benar menjadi perhatian konsumen. Jangan sampai konsumen dihadapkan pada janji janji palsu pengembang sebagai contoh, pengembang menjanjikan pada komplek perumahan akan di bangun taman bermain, namun hal tersebut seringkali diingkari. Untuk itu, konsumen harus menanyakan kepastian terhadap keseluruhan fasilitas yang ditawarkan oleh pengembang.

g. Harga tanah dan bangunan rumah, informasi akan dua hal tersebut akan memberikan gambaran kepada konsumen tentang total harga tanah dan rumah kemudian dibandingkan dengan harga jual yang telah di tambah dengan berbagai fasilitas dalam rumah dan fasilitas penunjang lain. Setelah itulah seorang konsumen dapat menyampaikan layak atau tidaknya harga jual rumah yang ditawarkan. Langkah ini ditempuh sebagai upaya rasionalisasi didalam membeli.

\section{Kontraktual}

Kontraktual adalah tahap yang ditempuh apabila proses persiapan pada tahap transaksi telah dilakukan, tahap selanjutnya adalah perjanjian jual-beli, yaitu setelah terjadi kata sepakat antara pengembang sebagai penjual dengan konsumen sebagai pembeli. Tahap perjanjian jual beli ini dilakukan dihadapan Pejabat Pembuat Akta Tanah (PPAT), serta ditandatangani oleh pengembang dan konsumen. Bagian ini merupakan tahap terjadinya penyesuaian pernyataan kehendak (kata sepakat) antara pihak pengembang dengan konsumen. Dengan adanya penyesuaian pernyataan kehendak dari kedua pihak maka terajdilah perjanjian jual-beli. Kemudian dilanjutkan dengan tahap penyerahan tanah sekaligus bangunan rumah dari pengembang kepada konsumen. Dengan adanya penyesuaian pernyataan kehendak dari kedua belah pihak maka terjadilah perjanjian 
jual beli. Kemudian dilanjutkan dengan tahap penyerahan tanah sekaligus bangunan rumah dari pengembang kepada konsumen. Pada tahap ini pengembang dan konsumen sepakat untuk menandatangani berita secara serah terima dan bangunan rumah.

Pada tahap transaksi jual beli rumah ada dua hal yang perlu diperjelas yaitu: berkaitan dengan sistem pembayaran jual beli rumah dan materi/isi transaksi pengikatan jual beli rumah.

a. Sistem pembayaran jual beli tanah

Pembayaran harga rumah beserta dengan tanahnya dapat ditempuh dengan beberapa cara, tetapi lazimnya digunakan dengan dua cara, yaitu : sistem pembayaran secara tunai maupun sistem angsuran. Sistem pembayaran secara tunai adalah mensyaratkan konsumen membayar sejumlah uang sekaligus sesuai dengan harga rumah yang telah disepakati dan diserahkan pada saat serah terima rumah. Adapun sistem angsuran, adalah mewajibkan konsumen membayar uang muka harga rumah dan sisanya diangsur sesuai dengan kesepakatan kedua belah pihak. Mengingat masyarakat yang kebanyakan membutukan rumah adalah mereka yang tergolong berpenghasilan rendah, maka cara yang seringkali dipilih adalah sistem pembayaran angsuran dengan menggunakan fasilitas Kredit Pemilikan Rumah (KPR) melalui bank pemberi kredit, dengan pembayaran angsuran setiap bulannya selama jangka waktu perjanjian kredit pemilikan rumah melalui bank pemberi kredit, seperti yang diatur dalam Kepmenpera: No. 05/KPTS/1985 jo Kepmenpera No. 08/KPTS/1995 dan Kepmenpera No. 02/KPTS/M/1996. Yang sekarang menjadi Permenpera No. 05 Tahun 2012 tentang Pengadaan Perumahan melalui Kredit/Pembiayaan. ${ }^{16}$

Pada saat konsumen menyetujui harga rumah berikut tanah untuk dibelinya, selanjutnya konsumen melakukan akad kredit pemilikan rumah (KPR) dengan prosedur yang telah ditentukan oleh bank pemberi kredit. Dengan adanya penandatanganan perjanjian kredit sekaligus konsumen memberi kuasa kepada Bank Pemberi Kredit (BPR) untuk membayarkan harga rumah berikut tanahnya yang dibeli kepada pengembang sebagai penjual tanah dan bangunan rumah yang

\footnotetext{
${ }^{16}$ Kepmenpera: No. 05/KPTS/1985 Jo Kepmenpera No. 08/KPTS/1995 dan Kepmenpera No. 02/KPTS/M/1996 Jo Permenpera No. 05 Tahun 2012 tentang Pengadaan Perumahan melalui Kredit/Pembiayaan
} 
dibeli konsumen dari pengembang menjadi agunan/jaminan atas pinjaman kredit dari Bank Pemberi Kredit.

b. Materi/isi transaksi pengikat jual beli rumah.

Hal paling utama yang perlu diperhatikan dalam transaksi jual beli adalah materi/isinya yang harus jelas. Terutama yang berkaitan dengan hak dan kewajiban para pihak harus seimbang, dan kemudian tidak bertentangan dengan peraturan Perundang-undangan yang berlaku, ketertiban umum dan kesusilaan.

\section{Post Kontraktual}

Pada tahap ini merupakan hasil realisasi transaksi jual beli rumah yang telah diselenggarakan. Konsumen telah dapat menikmati atau menempati tanah dan bangunan rumah yang telah dibeli dari pengembang. Beberapa hal yang dapat dilakukan konsumen dalam fase post kontraktual antara lain :

a. Penyerahan tanah dan bangunan rumah dan pengembang kepada konsumen dengan menandatangani berita acara serah terima.

b. Sebelum menandatangani berita acara serah terima, konsumen harus mencocokkan kembali keadaan rumah yang diperjanjikan. Apakah sudah sesuai ukuran tanah dan bangunan rumah, spesifikasi bangunan yang dignakan, fasilitas dalam rumah dan sebagainya.

c. Menggunakan fasilitas umum dan fasilitas sosial.

d. Penyerahan sertifikasi ketika konsumen telah melunasi harga tanah dan bangunan rumah.

Dari apa yang telah dijelaskan di atas konsumen mendapatkan gambaran bagaimana agar mendapatkan rumah sesuai dengan yang diinginkan, maka tiga (3) tahap penting ini yang harus diperhatikan oleh konsumen dalam melakukan jual-beli rumah mulai dari tahap prakontraktual, kontraktual dan post kontraktual yang ketiga tahap ini harus benar-benar dipahami dan dimengerti oleh konsumen sebelum melakukan jual-beli rumah.

Perumahan merupakan kumpulan rumah sebagai bagian dari Perumahan dan Kawasan Permukiman, baik perkotaan maupun pedesaan, yang dilengkapi dengan sarana, prasarana, dan utilitas umum sebagai hasil upaya pemenuhan rumah yang layak huni. Perumahan dan Kawasan Permukiman adalah bagian dari lingkungan hunian yang terdiri atas 
lebih dari satu satuan perumahan yang mempunyai sarana, prasarana, dan uilitas umum, serta mempunyai penunjang kegiatan fungsi lain dikawasan perkotaan atau kawasan pedesaan. ${ }^{17}$

Perumahan yang dimaksud mencakup rumah atau perumahan beserta Prasarana, Sarana, dan Utilitas umum. Hal ini juga ditegaskan kembali pada pasal 32 ayat (1) Undangundang 1 tahun 2011, yang mengatakan bahwa pembangunan perumahan meliputi:

1. Pembangunan rumah dan prasarana, sarana, dan utilitas umum dan/ atau

2. Peningkatan kualitas perumahan

Sebagaimana telah dijelaskan diatas merupakan sarana perumahan, dan permukiman, maka pihak yang membangun perumahan tersebut wajib menyediakan tempat penyediaan sarana dan prasarana terhadap perumahan.

Kewajiban dalam penyediaan sarana dan prasarana terhadap perumahan ini juga diperlihatkan dalam pasal 42 ayat (1) Jo. Pasal 42 ayat (2) Undang-undang No 1 tahun 2011 yang mengatakan bahwa rumah tunggal, rumah deret / atau rumah susun yang masih dalam tahap proses pembangunan dapat dipasarkan melalui sistem perjanjian pendahuluan jual-beli. Perjanjian pendahuluan jual beli dilakukan setelah memenuhi persyaratan kepastian atas:

1. Status kepemilikan tanah;

2. Hal yang diperjanjikan;

3. Kepemilikan izin untuk mendirikan bangunan induk;

4. Ketersediaan prasarana, sarana, dan utilitas umum; dan

5. Keterbangunan perumahan paling sedikit $20 \%$ (dua puluh persen)

Berdasarkan uraian di atas, dapat dikatakan bahwa penyediaan sarana dan prasarana terhadap perumahan sebagai salah satu perumahan dan permukiman, merupakan suatu kewajiban yang seharusnya diperjanjikan juga oleh si pembangun / pengembang. Dalam pasal 134 Undangundang No. 1 tahun 2011, dikatakan bahwa setiap orang dilarang menyelenggarakan pembangunan perumahan yang tidak membangun perumahan sesuai dengan kriteria, spesifikasi, persyaratan, prasarana, sarana, dan utilitas umum yang diperjanjikan

\footnotetext{
${ }^{17}$ Humas, http://asriman.com/pentingnya-menjadi-anggota-asosiasi-profesi-developer/
} 


\section{Akibat Hukum Dari Tanggung Jawab Pihak Pengembang Perumahan Berdasarkan Perjanjian Jual Beli Dengan Konsumen Di Kota Pekanbaru}

Dalam Pasal 129 dan Pasal 130 Undang-Undang Nomor 1 Tahun 2011 tentang Perumahan dan Kawasan Pemukiman. Dalam penyelenggaraan perumahan dan kawasan pemukiman, setiap orang berhak: ${ }^{18}$

menempati, menikmati, dan/atau memiliki/memperoleh rumah yang layak dalam lingkungan yang sehat, aman, serasi, dan teratur;

a. melakukan pembangunan perumahan dan kawasan permukiman;

b. memperoleh informasi yang berkaitan dengan penyelenggaraan perumahan dan kawasan permukiman;

c. memperoleh manfaat dari penyelenggaraan perumahan dan kawasan permukiman

Yang dimaksud dengan "manfaat" adalah keuntungan sebagai dampak dari penyelenggaraan perumahan dan kawasan permukiman, antara lain melalui kesempatan berusaha, peran masyarakat, dan pemanfaatan hasil pembangunan. Kemudian yang dimaksud dengan "informasi" adalah pengetahuan tentang penyelenggaraan perumahan dan kawasan permukiman yang antara lain meliputi peraturan, kebijakan, program, kegiatan, informasi kebutuhan dan penyediaan rumah, serta sumber daya yang dapat diakses. Di dalam Pasal 130 diatur bahwa dalam penyelenggaraan perumahan dan kawasan permukiman, setiap orang wajib: ${ }^{19}$

a. menjaga keamanan, ketertiban, kebersihan, dan kesehatan di perumahan dan kawasan permukiman;

b. turut mencegah terjadinya penyelenggaraan perumahan dan kawasan permukiman yang merugikan dan membahayakan kepentingan orang lain dan/atau kepentingan umum;

c. menjaga dan memelihara prasarana lingkungan, sarana lingkungan, dan utilitas umum yang berada di perumahan dan kawasan permukiman

Di samping itu pembangunan perumahan merupakan salah satu instrument terpenting dalam strategi pengembangan wilayah yang menyangkut aspek-aspek yang luas di bidang kependudukan dan berkaitan erat dengan pembangunan ekonomi dan kehidupan sosial dalam rangka pemantapan ketahanan nasional. Dalam pasal 1 angka 2 dan 7

\footnotetext{
${ }^{18}$ Undang-Undang Nomor 1 Tahun 2011 tentang Perumahan dan Kawasan Pemukiman

${ }^{19}$ Ibid
} 
Undang-undang No 1 tahun 2011 tentang Perumah dan Permukiman ditentukan bahwa: "Rumah adalah bangunan yang berfungsi sebagai tempat tinggal, atau hunian dan sarana pembinaan keluarga". "Perumahan adalah kelompok rumah yang berfungsi sebagai lingkungan tempat tinggal atau hunian yang dilengkapi dengan prasarana dan sarana lingkungan dimana manusia tinggal dan melangsungkan kehidupannya”.

Menurut bapak Indra Pomi Nasution, M.Si selaku Kepala Dinas Pekerjaan Umum Kota Pekanbaru yang penulis wawancarai mengatakan bahwa setelah dikeluarkan permendagri baru yang mengatur, jadi setelah membangun perumahan dan juga membangun fasos dan fasum, kemudian diserahkan kepada pemerintah. ${ }^{20}$

Lebih lanjut, ia juga mengatakan bahwa apabila pembeli / konsumen merasakan dirugikan oleh pengembang / pengembang, bisa melaporkannya ke pihak walikota dalam hal ini PTSP, dengan adanya laporan tersebut maka pihak dari pemerintah akan memblock orangnya bukan perusahaannya, karena mereka juga dapat mengganti perusahaan tetapi orangnya sama. $^{21}$

Menurut bapak Ardani ST.MT selaku Kepala Dinas Perumahan Kawasan Permukiman Kota Pekanbaru mengatakan bahwa apabila ada perumahan yang tidak membangun fasilitas yang dipersyaratkan, maka akan menimbulkan akibat hukum dan pembeli selaku konsumen yang mengalami kerugian tersebut, dapat mengadu ke pemerintah, atau ke pengadilan bahkan bisa ke pihak kepolisian. Untuk itu diharapkan kepada pengembang / pengembang lebih berhati-hati dan lebih merincikan pembangunan fasilitas umum yang ada diperumahan karena ke depannya akan ada audit BPK yang harus melihat fasilitas tersebut. ${ }^{22}$

Dapat diketahui bahwa rumah adalah bangunan dimana manusia tinggal dan melangsungkan kehidupannya, disamping itu rumah juga merupakan tempat berlangsungnya proses sosialisasi pada saat seseorang diperkenalkan kepada norma dan adat kebiasaan yang berlaku dalam masyarakat, maka tidaklah mengherankan bila masalah perumahan menjadi masalah yang penting bagi individu.

Upaya yang harus dilakukan Pemerintah yaitu, pemberdayaan konsumen melalui pembentukan Undang-undang yang secara khusus mengatur soal perlindungan konsumen

\footnotetext{
${ }^{20}$ Wawancara dengan bapak Indra Pomi Nasution, M.Si selaku Kepala Dinas Pekerjaan Umum Kota Pekanbaru, pada tanggal 13 Maret 2020

${ }^{21}$ Ibid

${ }^{22}$ Wawancara dengan bapak Ardani ST.MT selaku Kepala Dinas Perumahan Kawasan Permukiman Kota Pekanbaru, pada tanggal 4 Maret 2020
} 
perumahan sehingga dapat melindungi kepentingan konsumen secara integratif dan komprehensif. Secara kelembagaan, Pemerintah melakukan perbaikan atau penyempurnaan peraturan pelaksaanaan, pembinaan aparat, pranata dan perangkat-perangkat yudikatif, administratif dan edukatif, serta sarana dan prasarana lainnya agar nantinya undang-undang tersebut dapat diterapkan secara efektif oleh masyarakat.

Pemerintah perlu lebih berperan dalam menyediakan dan memberikan kemudahan dan bantuan perumahan dan kawasan permukiman bagi masyarakat melalui penyelenggaraan perumahan dan kawasan permukiman yang berbasis kawasan serta keswadayaan masyarakat sehingga merupakan satu kesatuan fungsional dalam wujud tata ruang fisik, kehidupan ekonomi, dan sosial budaya yang mampu menjamin kelestarian lingkungan hidup sejalan dengan semangat demokrasi, otonomi daerah, dan keterbukaan dalam tatanan kehidupan bermasyarakat, berbangsa, dan bernegara.

Pertumbuhan dan pembangunan wilayah yang kurang memperhatikan keseimbangan bagi kepentingan masyarakat berpenghasilan rendah mengakibatkan kesulitan masyarakat untuk memperoleh rumah yang layak dan terjangkau. Perumahan dan kawasan permukiman adalah satu kesatuan sistem yang terdiri atas pembinaan, penyelenggaraan perumahan, penyelenggaraan kawasan permukiman, pemeliharaan dan perbaikan, pencegahan dan peningkatan kualitas terhadap perumahan kumuh dan permukiman kumuh, penyediaan tanah, pendanaan dan sistem pembiayaan, serta peran masyarakat. Perumahan adalah kumpulan rumah sebagai bagian dari permukiman, baik perkotaan maupun perdesaan, yang dilengkapi dengan prasarana, sarana, dan utilitas umum sebagai hasil upaya pemenuhan rumah yang layak huni. Kawasan permukiman adalah bagian dari lingkungan hidup di luar kawasan lindung, baik berupa kawasan perkotaan maupun perdesaan, yang berfungsi sebagai lingkungan tempat tinggal atau lingkungan hunian dan tempat kegiatan yang mendukung perikehidupan dan penghidupan.

Hal yang perlu diperhatikan konsumen adalah pada saat serah terima fisik. Rumah yang diserahkan harus cocok spesifikasinya dengan yang ada di dalam perjanjian pengikatan jual beli. Jika tidak sesuai, maka hak konsumen untuk tidak menandatangani berita acara serah terima tersebut sebelum pengembang menyelesaikannya. ${ }^{23}$

Berdasarkan Peraturan Presiden Nomor 70 Tahun 2012 tentang perubahan kedua atas Peraturan Presiden Nomor 54 Tahun 2012 tentang Penyediaan Barang/Jasa Pemerintah, dalam

\footnotetext{
${ }^{23}$ Ermin Kallo, Perspektif Hukum Dalam Dunia Property, (Jakarta: Minerva Athena Pressindo, 2009), 48-50.
} 
Pasal 38 ayat 5 huruf h menyatakan bahwa: "Pekerjaan pengadaan Prasarana, Sarana, dan Utilitas Umum di lingkungan perumahan bagi masyarakat berpenghasilan rendah yang dilaksanakan oleh pengembang/pengembang yang bersangkutan”, maka untuk pelaksanaan pembangunan fisik prasarana, sarana, dan utilitas umum dimungkinkan untuk dilaksanakan dengan penunjukan langsung kepada pengembang/pengembang yang bersangkutan. ${ }^{24}$

Tugas pengembang perumahan yang membangun rumah diperuntukkan kepada masyaraakat berpenghasilan rendah berdasarkan buku panduan bantuan prasarana, sarana, dan utilitas umum perumahan dan kawasan Perumahan dan Kawasan Permukiman tahun 2013 yaitu : ${ }^{25}$

1. Mengajukan usulan bantuan prasarana, sarana, dan utilitas umum kepada pemerintah kabupaten/kota dan tembusan kepada kemenpera.

2. Membuat surat pernyataan kesanggupan membangun dari pengembang

3. Melaksanakan perjanjian kerjasama operasional dengan satuan kerja pengelolaan kawasan deputi bidang pengembangan kawasan sebagai dasar untuk melaksanakan pembagunan prasarana, sarana, dan utilitas umum

4. Melaporkan hasil pembangunan rumah yang telah KPR dan atau SP3K

5. Menyerahkan lahan yang akan dibangun prasarana, sarana, dan utilitas umum kepeada pemerintah sesuai dengan ketentuan peraturan perundang-undangan yang berlaku

6. Melaksanakan pembangunan prasarana,sarana, dan utilitas umum sesuai kontrak yang telah disepakati bersama antara pengembang dan pejabat pembuat komitmen (PPK)

7. Membangun unit rumah baru sesuai dengan jumblah usulan bantuan prasarana, sarana, dan utilitas umum

8. Menanam 1 (satu) pohon buah-buahan pada setiap unit rumah yang mendapatkan bantuan Prasarana,sarana, dan utilitas umum

9. Menyerahkan bantuan prasarana, sarana, dan utilitas umum kepada pemerintah kabupaten/kota sesuai dengan ketentuan peraturan perundang-undangan yang berlaku.

Menurut pasal 20 ayat 1 Undang-undang 1 tahun 2011 pada dasarnya penyelenggaraan perumahan tersebut tidak terlepas dari penyelenggaraan sarana yang meliputi:

\footnotetext{
${ }^{24}$ Peraturan Presiden Nomor 70 Tahun 2012 tentang perubahan kedua atas Peraturan Presiden Nomor 54 Tahun 2012 tentang Penyediaan Barang/Jasa Pemerintah

${ }^{25}$ Buku panduan bantuan prasarana, sarana, dan utilitas umum perumahan dan kawasan Perumahan dan Kawasan Permukiman tahun 2013, 8.
} 
1. Perencanaan perumahan;

2. Pembangunan perumahan;

3. Pemanfaatan perumahan; dan

4. Pengendalian perumahan.

Perumahan yang dimaksud mencakup rumah atau perumahan beserta Prasarana, Sarana, dan Utilitas umum. Hal ini juga ditegaskan kembali pada pasal 32 ayat (1) Undangundang 1 tahun 2011, yang mengatakan bahwa pembangunan perumahan meliputi:

1. Pembangunan rumah dan prasarana, sarana, dan utilitas umum dan/ atau

2. Peningkatan kualitas perumahan

Sebagaimana telah dijelaskan diatas merupakan sarana perumahan, dan permukiman, maka pihak yang membangun perumahan tersebut wajib menyediakan tempat penyediaan sarana dan prasarana terhadap perumahan.

Kewajiban dalam penyediaan sarana dan prasarana terhadap perumahan ini juga diperlihatkan dalam pasal 42 ayat (1) Jo. Pasal 42 ayat (2) Undang-undang No 1 tahun 2011 yang mengatakan bahwa rumah tunggal, rumah deret / atau rumah susun yang masih dalam tahap proses pembangunan dapat dipasarkan melalui sistem perjanjian pendahuluan jual-beli. Perjanjian pendahuluan jual beli dilakukan setelah memenuhi persyaratan kepastian atas:

1. Status kepemilikan tanah;

2. Hal yang diperjanjikan;

3. Kepemilikan izin untuk mendirikan bangunan induk;

4. Ketersediaan prasarana, sarana, dan utilitas umum; dan

5. Keterbangunan perumahan paling sedikit $20 \%$ (dua puluh persen)

Berdasarkan uraian di atas, dapat dikatakan bahwa penyediaan sarana dan prasarana terhadap perumahan sebagai salah satu perumahan dan permukiman, merupakan suatu kewajiban yang seharusnya diperjanjikan juga oleh si pembangun / pengembang. Dalam pasal 134 Undang-undang No. 1 tahun 2011, dikatakan bahwa setiap orang dilarang menyelenggarakan pembangunan perumahan yang tidak membangun perumahan sesuai dengan kriteria, spesifikasi, persyaratan, prasarana, sarana, dan utilitas umum yang diperjanjikan.

Akibat hukum yang dapat dilakukan apabila pengembang perumahan wanprestasi atau tidak dipenuhinya akan janji atas penyediaan sarana dan prasarana terhadap perumahan yang dapat dilakukan warga perumahan tersebut adalah menanyakan terlebih dahulu, 
prinsipnya adalah upayakan untuk menempuh penyelesaian permasalahan ini secara baikbaik. Jika tidak didapat titik temu dalam upaya perundingan tersebut, warga perumahan dapat melayangkan teguran/somasi terlebih dahulu yang isinya mengingatkan pengembang perumahan harus melaksanakan kewajibannya sampai batas waktu yang telah disepakati. Apabila waktu yg telah diperjanjikan terlewati, warga perumahan yang hak atas tempatnya tersebut belum terpenuhi, dapat memberikan tenggat waktu kepada pengembang perumahan untuk memenuhi kewajibannya.

Akibat Hukum Dari Penyelesaian Hukum Pembangunan Pengembang Perumahan Berdasarkan Undang Undang Nomor 1 Tahun 2011 Tentang Perumahan Dan Kawasan Permukiman Di Kota Pekanbaru adalah ganti rugi, dimana para konsumen sangat dirugikan oleh pengembang yang tidak melaksanakan aturan tersebut, pihak konsumen bisa melakukan gugatan pelaku usaha yang menjadi dasarnya adalah ganti kerugian.

\section{KESIMPULAN}

Adapun kesimpulan yang dapat diambil dari hasil penelitian yang telah dilakukan oleh penulis antara lain; Tanggung Jawab Pihak Pengembang Perumahan Berdasarkan Perjanjian Jual Beli Dengan Konsumen Di Kota Pekanbaru belum berjalan sebagaimana mestinya karena pengembang tidak bertanggungjawab, di dalam pasal 134 Undang-undang No. 1 tahun 2011, dikatakan bahwa setiap orang dilarang menyelenggarakan pembangunan perumahan yang tidak membangun perumahan sesuai dengan kriteria, spesifikasi, persyaratan, prasarana, sarana, dan utilitas umum yang diperjanjikan, para pengembang tidak dilaksanakan aturan itu, yaitu perumahan tersebut tidak memiliki fasos dan fasum (terutama sarana, prasarana, dan utilitas umum), dan ada perumahan yang tidak sesuai kriteria dan spesifikasinya yang diperjanjikan

Akibat Hukum Dari Tanggung Jawab Pihak Pengembang Perumahan Berdasarkan Perjanjian Jual Beli Dengan Konsumen Di Kota Pekanbaru adalah para konsumen perumahan dapat melakukan gugatan kepada pelaku usaha (pengembang) untuk ganti rugi atas tidak dilaksanakannya aturan tersebut.

\section{DAFTAR PUSTAKA}

Abdul Kadir Muhammad, 1990, Hukum Perikatan, (Bandung: Citra Aditya Bakti,) 
Ajiraksa, 2002, Perencanaan Dan Pengembang Perumahan, (Jakarta: Citra Adithya Bakti,)

Didik Rianto, 2006, Perencanaan Dan Pembangunan Perumahan, (Surabaya: PT. Tabah Jaya,)

Ermin Kallo, 2009, Perspektif Hukum Dalam Dunia Property, (Jakarta: Minerva Athena Pressindo,

Mursalim, 2002, Perencanaan Dan Pembuatan Fasilitas Perumahan, (Jakarta: Citra Adithya Bakti,)

Ni Luh Putu Eka Wijayanti, Keabsahan Sebuah Perjanjian Berdasarkan Dari Kitab Undang Undang Hukum Perdata, Bagian Hukum Bisnis Fakultas Hukum Universitas Udayana

Soedjajadi Keman, 2005, Kesehatan Perumahan Dan Lingkungan Pemukiman, Surabaya:

Sri Soedewi Masjchoen Sofwan, 1982, Hukum Perjanjian, (Yogyakarta: Universitas Gadjah Mada)

Undang-Undang Nomor 1 Tahun 2011 tentang Perumahan dan Kawasan Pemukiman

Peraturan Presiden Nomor 70 Tahun 2012 tentang perubahan kedua atas Peraturan Presiden Nomor 54 Tahun 2012 tentang Penyediaan Barang/Jasa Pemerintah

Kepmenpera: No. 05/KPTS/1985 Jo Kepmenpera No. 08/KPTS/1995 dan Kepmenpera No. 02/KPTS/M/1996 Jo Permenpera No. 05 Tahun 2012 tentang Pengadaan Perumahan melalui Kredit/Pembiayaan

Buku panduan bantuan prasarana, sarana, dan utilitas umum perumahan dan kawasan Perumahan dan Kawasan Permukiman tahun 2013

Humas, http://asriman.com/pentingnya-menjadi-anggota-asosiasi-profesi-developer/ http://www.rumahrakyat.org/content/persyaratan-menjadi-anggota-asosiasi-pengembangperumahan 